\title{
Foreign Presence and Industrial Concentration In Indonesian Food Industries
}

\author{
Dahlia Nauly ${ }^{1 *}$, Harianto ${ }^{2}$, Sri Hartoyo ${ }^{3}$, Tanti Novianti ${ }^{4}$ \\ ${ }^{*}$ Corresponding author
}

\begin{abstract}
Indonesia requires foreign investment to meet the capital needs of the food industries. On the other hand, foreign presence can cause high industrial concentration. This paper analyzes the effect of foreign presence on the concentration of the food industry in Indonesia using panel data from 28 subsectors in the period 2011-2015. The data used is the annual Large and Medium Industries Survey (IBS) data from Statistics Indonesia. The concentration indicators used are the concentration ratio (CR4) and the Herfindabl Hirschman Index (HHI). By using panel regression, the result shows that foreign presence has a positive influence on the concentration of the food industry in Indonesia. Besides, the economies of scale and market size also significantly influence the concentration of the food industry. The result indicates that the government investment policy must endorse more competition among firms.
\end{abstract}

Keywords: foreign presence, concentration, food industry

\begin{abstract}
Abstrak
Indonesia membutuhkan modal asing untuk memenuhi kebutuhan modal pada industri makanan. Disisi lain, keberadaan asing dapat menyebabkan tingginya konsentrasi industri. Tulisan ini menganalisis pengaruh keberadaan asing terhadap konsentrasi industri makanan di Indonesia dengan menggunakan data panel dari 28 subsektor pada periode tahun 2011-2015. Data yang digunakan adalah data survei tahunan Industri Besar dan Sedang (IBS) dari Badan Pusat Statistik (BPS). Indikator konsentrasi yang digunakan adalah rasio konsentrasi (CR4) dan Indeks Herfindahl Hirshman (HHI). Metode yang digunakan adalah regresi data panel. Hasilnya menunjukkan bahwa keberadaan asing memiliki pengaruh positif pada konsentrasi industri makanan di Indonesia. Selain itu skala ekonomi dan ukuran pasar secara signifikan juga mempengaruhi konsentrasi industri makanan. Dari hasil penelitian ini menunjukkan bahwa kebijakan investasi pemerintah harus lebih mendukung adanya persaingan antar perusahaan di dalam industri.
\end{abstract}

Kata Kunci: keberadaan asing, konsentrasi, industri makanan

JEL Classification Code: L66, L16

\section{How to Cite:}

Nauly, D., Harianto., Hartoyo, S., \& Novianti, T. (2020). Foreign Presence and Industrial Concentration in Indonesian Food Industry. Signifikan: Jurnal IImu Ekonomi, Vol. 9(1), 69-80. doi: http://dx.doi.org/10.15408/ sjie.v9i1.12200. 


\section{Introduction}

Indonesia has experienced a change in economic structure from an agrarian country to a new industrial country where the industry is the driving force for economic growth. One strategy undertaken by the government to encourage industrialization is to invite foreign investors in the form of foreign direct investment (FDI). It expected to have a positive impact on growth by providing additional funds available for investments, transferring technology and know-how, increasing employment, and promoting international trade (Liang, 2004). Besides, it is also supposed to have a positive effect on the volume of trade (Fetai \& Morina, 2018) and facilitate the transition to a market economy (Estrin \& Uvalic, 2014).

Foreign investment contribution to growth is clear in developed countries, but the results for the developing countries are rather mixed. The foreign investment significantly impacts the growth of developing countries. The countries with conditions such as politically stable, less corrupt, endowed with human capital, have access to broader domestic and foreign markets, as well as provide favorable economic environments, such as tax regime, and natural resources (Okafor \& Webster, 2016).

The influence of the presence of foreign firms on the degree of market concentration in the host country is still a debate in some literature. Concentration refers to an indicator of the number and size distribution of firms (Lipczynski, John, \& John, 2005). Some research argues that the existence of foreign firms can encourage competition, thereby reducing concentration (Blomström, 1986; Bourlakis, 1987; Dunning \& Lundan, 2008; Kejzar, 2011; Lall, 1979; Singh, 2011; Willmore, 1989). However, some literature states that the existence of foreign firms can reduce competition if the foreign firm is a large multinational company that is likely to become a monopolist in the industry (Rutkowski, 2006). This negative relationship also raised by several other researchers (Cho, 1990; Driffield, 2001a; Driffield, 2001b; Forte \& Sarmento, 2014; Ghemawat \& Kennedy, 1999), while other researchers showed positive and negative influences on concentration (Amess \& Roberts, 2005; De Backer \& Sleuwaegen, 2003).

Foreign presence could lead to crowding out of domestic firms and to an increase in concentration. Foreign presence leads to higher industry concentration in small economies. This condition is due to larger size and technological superiority of foreign firms compared to domestic firms (Blomström, 1986). Foreign entry is more likely to increase host-country industry concentration in developing economies (Amess \& Roberts, 2005).

Sarmento and Forte (2019) argue that foreign presence at the industry level increases a domestic firm's probability of exit from manufacturing sectors, and firms with foreign ownership have a lower possibility of exit than purely local firms. Besides being able to overcome capital constraints, the presence of foreign firms can also affect high concentration in the industries. Concentration increases the likelihood of collusive behavior (Gal \& Cheng, 2016). The concentration correlated with market power. High levels of concentration might be associated with various economic distortions (Aghion et al., 2001), which leads to political distortions and could be used to gain governmental protection from the potential competition (Ayal, 2013). That will happen when markets are small, and the business elite can establish 
additional formal or non-formal networks of influence from large firms. Bischoff \& Buchwald (2018) shows the linkages may be a mechanism to facilitate collusion that enhances economic power.

The food industry is an industry that is much in demand by foreigners in Indonesia. BKPM (2017) states that in 2010, the food industry occupies the highest position that receives foreign investment, with 31 percent of foreign investment in the manufacturing industry. In 2016 the percentage of foreign investment realization in this industry decreased to 13 percent, but this industry is still in the top five sectors that are of international interest.

Bird (1999) stated that almost all food and beverage subsectors in Indonesia have a high concentration, and this situation is persistent. It also concludes that the Indonesian food and beverage sector has an oligopoly market structure (Setiawan et al., 2012; Setiawan \& Oude Lansink, 2018). The presences of foreign firms are suspected to be the cause of the high concentration of the food industry in Indonesia. In the case of the USA, in the past decades, higher profit in the industries are related to higher concentration level (Grullon et al., 2019).

The objective of this paper is to analyze the impact of foreign presence on industrial food concentration in Indonesia. This study examines does the international presence in the food industry tends to increase the level of industrial concentration. This research contributes to the limited literature of Indonesia's case. This study has important policy implications, as it could help guide the regulatory authorities on the appropriate policy to increase competition among firms in the domestic market, especially in Indonesia's food industry.

The paper organized as follow. Section 2 provides methods employed with details on the econometric model, the proxy variables used, and the data sources. The results presented and discussed in section 3. The last section presents conclusions and policy implications.

\section{Methods}

To analyze the impact of foreign companies on the concentration of food industry groups in Indonesia, the balanced panel data period of 2011-2015 is using. This data is the Annual Medium and Large Industry Survey (IBS) conducted by Statistics Indonesia. This period applies to avoid bias from the 2008 financial crisis; in addition, data after 2015 not yet available during this article is written. IBS is an establishment-level data. The industrial concentration can only be estimated at the subsector level. Therefore the model is calculated at the subsector level.

From 2011 to 2015, there was an increase in the number of establishments surveyed. In 2011 there was 5464 establishment, and in 2015, the number increase to 6445 establishments. Data is arranged in a panel; therefore, there are 1335 establishment used. Some data are excluded from this study to avoid the error. These data are the establishments that do not have the value of capital and sales. To obtain concentration and other industrylevel characteristics, individual establishment-level data aggregated for a given industry at the 5-digit level.

This research utilized 28 subsectors at the 5-digit level of the International Standard Industrial Classification (ISIC) system. The codes used are coming from the Klasifikasi Baku 
Lapangan Usaha Indonesia (KBLI), which is comparable to the ISIC codes. The original data covered 75 subsectors. The subsector less than ten establishments are combined at the 4-digit ISIC level resulting in 28 subsectors in the period 2011 until 2015.

The industrial concentration in this study using the concentration ratio (CR4) and the Herfindahl Hirschman Index (HHI). CR4 is the sum of sales shares of four large establishments in a subsector. While HHI is the sum of the squared sales shares of all establishment shares in the subsector. Both the CR4 and the HHI measures have a limitation in the calculation, but they complement each other (Setiawan et al., 2012; Setiawan \& Oude Lansink, 2018). CR4 is usually used to classify markets in several oligopoly categories, but cannot capture the distribution of market shares of all firms in a market. While HHI can obtain the distribution of the firm's market share in a market, but it is difficult to classify the oligopoly category of HHI.

Bird (1999) and Setiawan et al. (2012), who has conducted research related to industrial concentration in Indonesia, stated that the calculation of industrial concentration in Indonesia has several weaknesses. First, the survey of manufacturing industries in Indonesia is only for the medium and large industries. Second, the data used is not firm data but plant (establishment) data; therefore, there is a possibility that one firm has more than one establishment. Third, the unavailability of information in data related to mergers; therefore, there is a possibility of calculations being underestimated. Fourth, the industries examined may not be 'markets.' However Bird (1999) also states that the resulting bias calculation is not substantial. Also, Hill (1987) argues that in the aggregate, the exclusion of small companies is not a serious problem. Differences in results can occur due to differences in the methods used in the calculation, but the tendency is still to capture quite accurately. Lastly, in Indonesia, vertical mergers are more than horizontal. Therefore they do not have much effect on calculations.

The industry concentration model explained by the presence of foreign companies in each subsector (as independent variables) and some relevant industry characteristics, especially barriers to entry, market size, and growth. The concentration equation used is as follows:

$$
\begin{aligned}
& C R 4_{i t}=\beta_{0}+\beta_{1} F_{i t}+\beta_{2} E S_{i t}+\beta_{3} C I_{i t}+\beta_{4} M G_{i t}+\beta_{5} M S_{i t}+\varepsilon_{i t} \\
& H H I_{i t}=\beta_{0}+\beta_{1} F_{i t}+\beta_{2} E S_{i t}+\beta_{3} C I_{i t}+\beta_{4} M G_{i t}+\beta_{5} M S_{i t}+\varepsilon_{i t}
\end{aligned}
$$

Where CR4 is the concentration ratio; HHI is the Herfindahl Hirschman index; F is foreign presence; ES is economies of scale; CI is capital intensity (million rupiahs/ person); MG is market growth (\%); MS is the market size (million rupiahs); and ${ }^{\varepsilon}{ }_{\text {it }}$ is disturbance term in subsector-i in year $\mathrm{t}$.

The foreign presence calculated from the international firms' share of sales to the industry total sales (Driffield, 2001; Ghemawat \& Kennedy, 1999; Singh, 2011). Sales were deflated by the consumer price index of food and beverage products (the base year 2000) to eliminate the effect of inflation. This research defines a foreign firm as a firm having a definite amount of foreign ownership. The resulting sign will be the answer to the research problem. 
The main determinants affecting market concentration is the presence of barriers to entry. Entrance barriers quantified by using variable economies of scale and capital intensity. Opportunities to obtain economies of scale are measured using the ratio of the average size of establishments, which accounts for the top 50 percent of total sales of the industry divided by the total sales of the industry. This calculation is similar to that of Lall (1979), Amess \& Roberts (2005), and Forte \& Sarmento (2014). The economies of a scale measure the number of firms that can accommodate the industry and the given market size. Whether a particular sector will be a higher or less concentrated industry (Adam \& Khalifah, 2012), the higher minimum efficiency of scale relative to the industrial output means that few firms can be accommodated within the industry (Kambhampati, 2000). The expected sign on the economies of scale variable on industrial concentration is positive.

Capital intensity is an entry barrier that shows a minimum capital amount of necessary capital for efficient production (Adam \& Khalifah, 2012). It is the ratio of total assets to the total number of employees in the industry (Adam \& Khalifah, 2012; Bourlakis, 1987; De Backer \& Sleuwaegen, 2003; Forte \& Sarmento, 2014; Lall, 1979; Singh, 2011). Total assets data obtained from fixed asset values deflated by the consumer price index. The higher intensity of capital expected to have a positive influence on concentration.

Market size and market growth rates variables reflect entry opportunities. The size of the efficient firms needed. A growing market demand would attract new firms to enter and allow incumbent firms to survive, resulting in a lower concentration. he market size measured with sales in each industry (Amess \& Roberts, 2005; Bourlakis, 1987). The market growth rate is a percentage growth of sales of each industry (Bourlakis, 1987; De Backer \& Sleuwaegen, 2003; Forte \& Sarmento, 2014; Singh, 2011; Willmore, 1989). Large market size and increasingly high industrial growth accommodate more companies. A negative correlation between concentration and all market opportunities and market growth leads to lower concentration.

This study uses a single equation to inves tigate the impact of foreign presence on concentration in the Indonesian food ind ustry. The fixed effect and random effect models are estimated to account for any unobservable heterogeneity of the industry. The Hausman specification used to compare random effects against fixed-effect models to choose the best statistical model. If the Hausman test shows that there is a correlation between individual effects and other regression, the fixed-effect model will be chosen.

\section{Result and Discussion}

The descriptive statistics show in Table 1 . Table 1 indicates that the data are relatively heterogeneous. The standard deviation among subsectors is quite high for all variables. It observes that the average of CR4 is 0.626 . This result means that, on average, 62.60 percent of sales in the food industry controlled by four companies. The calculation of the average value of CR4 and HHI produced is almost similar to Setiawan et al. (2012) with a CR4 value of 0.633 and HHI 2266 in the period 1995-2006. In the 1980-2014 period, Setiawan \& Lansink (2018) shows a CR4 value of 0.645 . This value characterizes the food industry as an oligopoly. 
Table 1. Descriptive Statistics

\begin{tabular}{lccccc}
\hline & Variables & Average & $\begin{array}{c}\text { Standard } \\
\text { Deviation }\end{array}$ & Min & Max \\
\hline CR4 & & 0.626 & 21.93 & 0.113 & 0.973 \\
HHI & & 1975.42 & 1608.53 & 111.70 & 6753.44 \\
Foreign Presence & (\%) & 14.88 & 18.28 & 0 & 85.67 \\
Economies of Scale & & 6.77 & 4.33 & 0.80 & 16.20 \\
Capital Intensity & (million rupiah /person) & 75.56 & 79.23 & 6.34 & 583.79 \\
Market Growth & (\%) & 16.73 & 38.78 & -75.93 & 195.29 \\
Market Size & (million rupiah) & 2500.06 & 4559.03 & 63.88 & 26000.53 \\
N-observation & & 140 & 140 & 140 & 140 \\
\hline
\end{tabular}

Source: Statistics Indonesia and authors' calculation

The average CR4 value for the period 2011-2015 shows that the most concentrated subsector is the food-seasoning industry (0.933), processed food (0.896), other processing and preserving fish $(0.893)$, macaroni and noodles $(0.866)$. The subsector that has low concentration (below 0.3 ) are rice and corn milling industries (0.146), crackers (0.269) and tempeh, tofu, and soybean processing (0.277). Table 2 shows the average value of CR4, HHI, and foreign presence in each subsector.

Based on foreign presence, subsectors that have the highest percentage are canned fish, shrimp and other aquatic biota industries (62.04\%), cocoa confectionary, chocolate, dried fruit and vegetable $(47.74 \%)$, processing and preservation of other aquatic biota $(44.53 \%)$ and frozen fish $(38.88 \%)$. While, there are seven subsectors which foreigners do not own capital such as: the salted, pulverized, dried, frozen fruit and vegetable industries, tempeh, tofu and soybean, fruit and vegetable processing, rice and corn milling, macaroni and noodles, processed food, cakes, other food from soybean (not fermented soybean, tempeh, and tofu).

Subsectors that have the highest average economies of scale are processed food (15.89), food seasoning (13.97), preserving and processing fruits and vegetables (13.44), the processed product from milk and ice cream (13.34) and canned fish, shrimp and another aquatic biota (13.33). At the same time, the lowest economies of scale are rice and corn milling (0.80), bakery products (1.02), and crackers (1.20).

Subsectors with the highest average capital intensity are the canned fish, shrimp and other aquatic biota (214.79), crude palm oil (173.89), processed product from milk and ice cream (161.22) and the animal feed industry (156.70). Whereas those with the lowest average capital intensity are (24.09), processing and preserving meat (29.16), crackers (29.74), salted, pulverized, dried, frozen fruit and vegetable (29.88).

The highest average market growth occurred in the soy sauce industry $(53.03 \%)$, salted, dried, smoked fish (39.88\%), processed coffee and tea (35.39\%), and food seasoning $(31.96 \%)$. However, several industry groups throughout 2011-2015 had an average negative growth, namely the cocoa confectionery, chocolate, dried fruit and vegetable 
$(-15.10 \%)$, canned fish, shrimp, and other aquatic biota industries $(-8.77 \%)$ and processed salt $(-2.78 \%)$.

Table 2. Average values of CR4, HHI and Foreign Presence for each subsector in the Indonesian food industry, 2011-2015

\begin{tabular}{|c|c|c|c|c|}
\hline ISIC & Subsector & CR4 & $\mathrm{HHI}$ & $\begin{array}{l}\text { Foreign } \\
\text { Presence }\end{array}$ \\
\hline 10100 & Processing and preserving meat & 0.780 & 2328.8 & 0.3 \\
\hline 10211 & Salted, dried, smoked fish & 0.709 & 2109.7 & 0.9 \\
\hline 10213 & Frozen fish & 0.493 & 1142.1 & 38.9 \\
\hline 10214 & Preserved fish & 0.596 & 1191.0 & 14.8 \\
\hline 10219 & Other processing and preserving fish & 0.893 & 2887.4 & 13.3 \\
\hline 10221 & Canned fish, shrimp and other aquatic biota & 0.757 & 2503.2 & 62.0 \\
\hline 10290 & Other processing and preserving aquatic biota & 0.586 & 1226.4 & 44.5 \\
\hline 10310 & Salted, pulverized, dried, frozen fruit and vegetable & 0.858 & 3364.4 & 0.0 \\
\hline 10390 & Tempeh, tofu and soybean, fruit and vegetable processing & 0.277 & 367.3 & 0.0 \\
\hline 10420 & Copra, coconut oil and other coconut processing & 0.690 & 1653.1 & 18.7 \\
\hline 10431 & Crude palm oil & 0.260 & 305.9 & 26.0 \\
\hline 10500 & Processed product from milk and ice cream & 0.719 & 1633.5 & 35.4 \\
\hline 10610 & Rice and seed, coffee and cocoa milling and cleaning & 0.841 & 4452.5 & 9.1 \\
\hline 10620 & Seed, beans and roots cleaning & 0.487 & 789.4 & 17.1 \\
\hline 10630 & Rice and corn milling & 0.146 & 139.5 & 0.0 \\
\hline 10710 & Bakery products & 0.435 & 639.1 & 20.8 \\
\hline 10720 & Sugar & 0.582 & 1310.3 & 0.6 \\
\hline 10730 & Cocoa confectionary, chocolate, dried fruit and vegetable & 0.762 & 1943.4 & 47.7 \\
\hline 10740 & Macaroni and noodles & 0.866 & 5443.6 & 0.0 \\
\hline 10750 & Processed food & 0.896 & 5152.2 & 0.0 \\
\hline 10761 & Processed coffee and tea & 0.593 & 1234.2 & 5.8 \\
\hline 10771 & Soy sauce & 0.567 & 2037.7 & 1.1 \\
\hline 10772 & Food seasoning & 0.933 & 3961.9 & 8.8 \\
\hline 10774 & Processing Salt & 0.648 & 1973.4 & 36.0 \\
\hline 10792 & Cakes & 0.603 & 1304.6 & 0.0 \\
\hline 10793 & $\begin{array}{l}\text { Other food from soybean (not fermented soybean, tempeh, } \\
\text { and tofu) }\end{array}$ & 0.824 & 3117.1 & 0.0 \\
\hline 10794 & Crackers & 0.269 & 317.1 & 0.2 \\
\hline 10800 & Animal feed and concentrate & 0.460 & 782.7 & 14.5 \\
\hline
\end{tabular}

The empirical results show in Table 3. The Hausman test statistics indicate that using the fixed-effect model is more appropriate than the random effect model. The fixed-effect model also produces $\mathrm{R}^{2}$ that is greater than the random effect. Therefore, only the fixed effect model estimation will discuss.

Based on Table 3, it can show that the foreign presence has a positive impact on industrial concentration. The positive and statistically significant sign on the estimated 
coefficient inferred that industries with a higher sales share of foreign firms have a higher concentration ratio. The results are consistent with Blomström (1986), Bourlakis (1987), Lall (1979), and Singh (2011) that have also found a positive relationship between the presence of multinationals and industrial concentration. According to the literature, this positive relationship indicates that local plants cannot compete with foreign plants.

The positive relationship between foreign presence and industry concentration can cause that international firms have intensive knowledge and capital, and their existence causes an increase in barriers to entry. Besides, foreign firms tend to have some funds from banks, blocking the entrance of new companies, and creating barriers to entry (Bourlakis, 1987). The specific advantages of foreign firms increase the level of entry barriers for domestic firms. International firms, as multinational companies, can use a predatory approach (Blomström, 1986). This result also shows that in the food industry, domestic firms cannot compete with foreign firms.

Table 3. Panel Estimation Results

\begin{tabular}{lcccc}
\hline \multirow{2}{*}{ Independent Variables } & \multicolumn{2}{c}{ Dependent variable CR4 } & \multicolumn{2}{c}{ Dependent variable HHI } \\
\cline { 2 - 5 } & Fixed Effect & Random Effect & Fixed Effect & Random Effect \\
\hline \multirow{2}{*}{ Foreign Presence } & $0.147^{* *}$ & $0.162^{* *}$ & $24.363^{* * *}$ & $14.990^{*}$ \\
& $(0.074)$ & $(0.075)$ & $(9.636)$ & $(9.034)$ \\
Economics Scale & $18.665^{* * *}$ & $4.237^{* * *}$ & $2006.237^{* * *}$ & $223.175^{* * *}$ \\
& $(3.150)$ & $(0.862)$ & $(412.958)$ & $(67.387)$ \\
Capital Intensity & 0.003 & 0.007 & -0.576 & -0.095 \\
& $(0.007)$ & $(0.007)$ & $(0.930)$ & $(1.032)$ \\
Market Growth & $0.027^{* *}$ & $0.047^{* * *}$ & 2.427 & $5.590^{* * *}$ \\
& $(0.012)$ & $(0.013)$ & $(1.620)$ & $(1.735)$ \\
Market Size & $0.002^{* * *}$ & $0.001^{* * *}$ & $0.280^{* * *}$ & $0.153^{* * *}$ \\
& $(0.000)$ & $(0.000)$ & $(0.060)$ & $(0.048)$ \\
Constant & $-71.986^{* * *}$ & $26.482^{* * *}$ & $-12737.19^{* * *}$ & -208.751 \\
$R^{2}$ & $(21.068)$ & $(7.164)$ & $(2761.881)$ & $(574.527)$ \\
N-observation & 0.476 & 0.377 & 0.432 & 0.303 \\
\hline
\end{tabular}

Source: authors' calculation

Standard errors in parentheses

"**,* and ${ }^{*}$ indicate $1 \%, 5 \%$ and $10 \%$ significance levels, respectively

Economies of scale show a positive and significant coefficient. The result means that higher economies of scale tend to have higher concentration ratios. Similar results also found by early studies (Adam \& Khalifah, 2012; Amess \& Roberts, 2005; Blomström, 1986; Lall, 1979; Ratnayake, 1999). The result for capital intensity has expected positive sign that has failed to gain a statistically significant coefficient.

The market size variable is statistically significant. The sign of the coefficient for this variable was the opposite of that expected. The positive and statistically significant coefficient implies that larger industries tend to present a higher concentration ratio. Forte 
\& Sarmento (2014) have the same result in Portuguese manufacturing industries. One possible explanation is that more total sales of the sector are due to the increase in sales of four establishments that have the most significant transactions.

Based on the magnitude of the coefficient, it can show that foreign presence and economies of scale are the leading causes of the high concentration of the food industry in Indonesia. A non-ministerial government institution responsible for investment in Indonesia is the Investment Coordinating Board, starting now referred to as BKPM. Regulation of BKPM number 13 of 2017 concerning Licensing Guidelines and Procedures and Investment Facilities which updated with the law of BKPM No. 6 of 2018 states that foreign investors are foreign nationals, foreign business entities, and/or foreign governments that carry out investment in the territory of the Republic of Indonesia. Foreign investment companies qualify as large businesses. Large businesses have a net worth of more than 10 billion rupiahs and have annual sales of more than 50 billion rupiahs. Based on these regulations, foreign firms must be large companies that also have large economic scale. This condition can cause domestic firms challenging to compete with international firms. Therefore international presence causes low competition and a high concentration of industry.

Besides, the results show that increasing market size increases the concentration in the food industry. The increase in market size is not due to the increasing number of companies. But, because of the growing sales of large companies in the industry. This condition can happen because the government provides facilities that are more beneficial to large companies. Law No. 25 of 2007 concerning Investment states that the government provides facilities to investors who conduct business expansion or make new investments in the form of: a) income tax through a reduction in net income to a certain degree to the amount of investment made in a certain time; b) exemption or relief of import duty on the import of capital goods, machinery, or equipment for production purposes that cannot yet be produced domestically; c) exemption or relief of import duties on raw materials or auxiliary materials for production purposes for a certain period of time and certain requirements; d) exemption or suspension of Value Added Tax on the import of capital goods or machinery or equipment for production purposes that cannot be produced domestically for a certain period of time.

Based on this, competition among firms in the industry must endorse investment policies. To decrease concentration, foreign firms do not have to be a large company. Domestic firms do not always have to be protected, so they must compete with international firms.

\section{Conclusion}

This study investigates the impact of foreign presence on industrial food concentration, using the Annual Medium and Large Industry Survey from Statistics Indonesia. It used panel data regression with 28 subsectors in the period 2011-2015. The results indicate that on average and after controlling for capable of influencing industry concentration, foreign presence tends to increase industrial concentration. Economies of scale and market size also have a significant effect on industry concentration. 
The results have important policy implications regarding foreign investment in the Indonesian food industry. Policymakers should promote competition and reduce industrial concentration. Policies must direct so that domestic firms can compete with international firms. The same research in different sectors needs to done to see the effects that may be different.

\section{References}

Adam, R., \& Khalifah, N. A. (2012). Foreign Presence and Market Concentration in Malaysian Manufacturing Industries. Jurnal Ekonomi Malaysia, 46(1), 119-132.

Aghion, P., Harris, C., Howitt, P., \& Vickers, J. (2001). Competition, Imitation and Growth with Step-by-step Innovation. Review of Economic Studies, 68(3), 467-492.

Amess, K., \& Roberts, B. M. (2005). The Impact of Foreign and State Ownership on PostTransition Industrial Concentration: The Case of Polish Manufacturing. Economic Change and Restructuring, 38, 211-225.

Ayal, A. (2013). The Market for Bigness: Economic Power and Competition Agencies' Duty to Curtail It. Journal of Antitrust Enforcement, 1(2), 221-246.

Bird, K. (1999). Concentration in Indonesian Manufacturing, 1975-1993. Bulletin of Indonesian Economic Studies, 35(35), 43-73.

Bischoff, O., \& Buchwald, A. (2018). Horizontal and Vertical Firm Networks, Corporate Performance and Product Market Competition. Journal of Industry, Competition and Trade, 18(2), 25-45.

BKPM. (2017). Perkembangan_Realisasi_Investasi_PMA_Menurut_Sektor_Q2_2017. Retrieved from https://www.bkpm.go.id/id/statistik/investasi-langsung-luar-negeri-fdi

Blomström, M. (1986). Multinationals and Market Structure in Mexico. World Development, 14, 523-530. https://doi.org/10.1016/0305-750X(86)90067-7.

Bourlakis, C. A. (1987). Multinational Corporations and Domestic Market Structure: The Case of Greek Manufacturing Industries. Weltwirtschaftliches Archiv, 123, 719-733.

Cho, K. R. (1990). Foreign Banking Presence and Banking Market Concentration: The Case of Indonesia. The Journal of Development Studies, 27(1), 98-110. https://doi.org/ 10.1080/00220389008422185.

De Backer, K., \& Sleuwaegen, L. (2003). Does Foreign Direct Investment Crowd Out Domestic Entrepreneurship? Review of Industrial Organization, 22(1), 67-84. https:// doi.org/10.1023/A:1022180317898.

Driffield, N. (2001). Inward Investment and Host Country Market Structure: The Case of The U.K. Review of Industrial Organization, 18(4), 363-378.

Driffield, Nigel. (2001). Inward Investment, Industry Concentration and The Speed of Adjustment. Weltwirtschaftliches Archiv, 137(2), 193-214.

Dunning, J. H., \& Lundan, S. M. (2008). Multinational Enterprises and the Global Economy, Second Edition. United Kingdom: Edward Elgar Publishing Limited. 
Estrin, S., \& Uvalic, M. (2014). FDI Into Transition Economies: Are the Balkans Different? Economics of Transition, 22(2), 281-312.

Fetai, B., \& Morina, F. (2018). The Impact of Foreign Direct Investment on Press Freedom. Working Paper. Center for Economic Theories and Policies Sofia University St. Kliment Ohridski Faculty of Economics and Business Administration.

Forte, R., \& Sarmento, P. (2014). Does FDI Increase Market Concentration? An Evaluation of the Portuguese Manufacturing Industries. Acta Oeconomica, 64(4), 463-480.

Gal, M. S., \& Cheng, T. K. (2016). Aggregate Concentration: A Study of Competition Law Solutions. Journal of Antitrust Enforcement, 4(2), 282-322.

Ghemawat, P., \& Kennedy, R. E. (1999). Competitive Shocks and Industrial Structure: The Case of Polish Manufacturing. International Journal of Industrial Organization, 17(6), 847-867. https://doi.org/10.1016/S0167-7187(97)00065-9.

Grullon, G., Larkin, Y., \& Michaely, R. (2019). Are US Industries Becoming More Concentrated?. Review of Finance, 23(4), 697-743.

Hill, H. (1987). Concentration in Indonesian Manufacturing. Bulletin of Indonesian Economic Studies, 23(2), 71-100. https://doi.org/10.1080/00074918712331335201.

Kambhampati, U. S. (2000). Industry Competitiveness: Leadership Identity and Market Shares. Applied Economics Letters, 7(9), 569-573. https://doi.org/10.1080/ 13504850050059023.

Kejzar, K. Z. (2011). The Role of Foreign Direct Investment in the Host-Country Firm Selection Process: Firm-Level Evidence from Slovenian Manufacturing. Review of World Economics, 147(1), 169-193. https://doi.org/10.1007/s10290-010-0077-3.

Lall, S. (1979). Multinationals and Market Structure in an Open Developing Economy: The Case of Malaysia. Weltwirtschaftliches Archiv, 115, 325-350.

Liang, G. (2004). New Competition; Foreign Direct Investment and Industrial Development in China. Retrieved from http://repub.eur.nl/resource/pub_1795/

Lipczynski, J., John, W., \& John, G. (2005). Industrial Organization, Competition, Strategy, Policy (Second). Harlow, England: Pearson Education Limited.

Okafor, G., \& Webster, A. (2016). FDI in Transition Economies of Europe and the Former Soviet Union. In J. Holscher \& H. Tomann (Eds.), Palgrave Dictionary of Emerging Markets and Transition Economics (pp. 413-434).

Ratnayake, R. (1999). Industry Concentration and Competition: New Zealand Experience. International Journal of Industrial Organization, 17, 1041-1057. https://doi.org/10.1016/ S0167-7187(97)00069-6.

Rutkowski, A. (2006). Inward FDI, Concentration, and Profitability in the CEECs: Were The Domestic Firms Crowded Out or Strengthened? Transnational Corporations, 15(3), $107-141$.

Sarmento, P., \& Forte, R. (2019). Does Foreign Presence Induce Host Country Firms' Exit? The Case of Portugal. International Advances in Economic Research, 25(3), 323-337. https://doi.org/10.1007/s11294-019-09744-5. 
Setiawan, M., Emvalomatis, G., \& Lansink, A. O. (2012). Industrial Concentration and Price-Cost Margin of The Indonesian Food and Beverages Sector. Applied Economics, 44, 3805-3814. https://doi.org/10.1080/00036846.2011.581220.

Setiawan, M., \& Oude Lansink, A. G. J. M. (2018). Dynamic Technical Inefficiency and Industrial Concentration in The Indonesian Food and Beverages Industry. British Food Journal, 120(1), 108-119. https://doi.org/10.1080/02692171.2019.1606900.

Singh, J. (2011). Inward Investment and Market Structure in an Open Developing Economy: a Case of India's Manufacturing Sector. Journal of Economics and Behavioral Studies, 2(6), 286-297.

Willmore, L. (1989). Determinants of Industrial Structure: A Brazilian Case Study. World Development, 17(10), 1601-1617. https://doi.org/10.1016/0305-750X(89)90031-4. 